\title{
Pathophysiology, prevention, and treatment of acute graft-versus-host disease
}

This article was published in the following Dove Press journal:

Transplant Research and Risk Management

3 March 20II

Number of times this article has been viewed

\author{
Abhinav Deol \\ Voravit Ratanatharathorn \\ Joseph P Uberti \\ Department of Oncology, \\ Blood and Marrow Stem Cell \\ Transplant Program, Barbara Ann \\ Karmanos Cancer Institute, Wayne \\ State University School of Medicine, \\ Detroit, MI, USA
}

\begin{abstract}
Acute graft-versus-host disease (aGVHD) is an immunologically mediated inflammatory reaction, which continues to be a major cause of morbidity and mortality in patients undergoing allogeneic hematopoietic stem cell transplant. Although the occurrence and severity of this disease may be devastating, there is a proven immunologically mediated antitumor activity that accompanies the disease process, which has a beneficial effect on outcome. Animal models of graft-versus-host disease (GVHD) have given us a conceptual model that has allowed a better understanding of the pathophysiology and offers a framework for understanding the complex interactions between antigen-presenting cells, donor T-cells, and cytokines in the development of aGVHD. It has also given us a model that allows testing of various strategies for prevention and treatment. New, innovative approaches for treatment and prevention of aGVHD including better donor selection with the use of sophisticated human leukocyte antigen typing, use of T-cell depletion, reduced-intensity transplant regimens, and improved pharmacologic immunosuppression have improved outcomes by decreasing the incidence and severity of aGVHD. However, the limitation of these strategies is that effective treatment and prevention of aGVHD is often accompanied by a concomitant rise in relapses, graft failure and infections, and ultimately no improvement in overall survival. Investigators are working on understanding the difference between GVHD and graft versus tumor effect, as this would be the key in improving outcomes for our patients. In this review, we will discuss the pathophysiology of aGVHD along with the preventative and treatment strategies.
\end{abstract}

Keywords: acute GVHD, GVHD, acute graft-versus-host disease, bone marrow transplant

\section{Introduction}

Over the last five decades, allogeneic hematopoietic stem cell transplant (HSCT) has become the treatment of choice for many hematologic malignancies, immunodeficiency disorders, hemoglobinopathies, genetic disorders, and aplastic anemia. The outcomes of transplantation have improved due to improvements in supportive care, high-resolution human leukocyte antigen (HLA) typing that allows for better donor matching, and an increased use of reduced-intensity transplant regimens. In spite of increasing understanding and application of the procedure in various hematologic diseases, the efficacy of the procedure is limited by graft-versus-host disease (GVHD). This immunologically mediated inflammatory reaction that often accompanies allogeneic transplantation remains a major cause of mortality and morbidity in patients undergoing allogeneic HSCT.

GVHD had historically been divided into acute and chronic, with a somewhat arbitrary 100-day boundary separating the two entities. With clinical experience and 
better understanding of the physiology involved, the HSCT community for the past few years has realized the limitations of this classification. In 2005, the National Institute for Health consensus statement on classification of GVHD was adopted as a guideline to define and differentiate acute graft-versus-host disease (aGVHD) and chronic GVHD. ${ }^{1}$ This classification is shown in Table 1.

The incidence of aGVHD in patients undergoing allogeneic HSCT is $40 \%-60 \%{ }^{2-5}$ The median time from transplant to diagnosis of aGVHD depends on the intensity of preparative regimens utilized ranging from 17 days for full-intensity myeloablative regimens ${ }^{6}$ to 3 months for reduced-intensity regimens. $^{7}$

The main factors that increase the risk of developing aGVHD include degree of HLA disparity, advanced age of donor and/or recipient, sex mismatch, and intensity of the preparative regimen. ${ }^{5,8}$ In addition, a recent meta-analysis showed that the increased use of peripheral blood stem cells in place of marrow stem cells might contribute to an increased risk of aGVHD. ${ }^{9}$ Previous studies, however, have suggested no difference in the incidence of aGVHD based on the source of stem cells. ${ }^{10-12}$

\section{Pathophysiology of aGVHD}

In 1966, Billingham postulated that development of GVHD requires three factors: ${ }^{13} 1$ ) the graft must contain immunologically competent cells, 2) the host must possess important alloantigens that are lacking in the donor graft, so that the host appears foreign to the graft and can, therefore, stimulate it antigenically, and 3) the host must be incapable of mounting an effective immunologic reaction against the graft.

Our understanding of the pathophysiology of aGVHD has been aided by established animal models. HLA, the most immunogenic protein in humans, is expressed by genes encoded by the 'major histocompatibility complex' (MHC). The degree of disparity in HLA gene expression is the strongest predictor for aGVHD, and for this reason, the vast majority of transplants are performed from fully matched HLA-related or unrelated donors..$^{814-16}$ However,
aGVHD still occurs in up to $40 \%-60 \%$ of such transplants implicating polymorphic genes outside of the MHC, referred to as minor histocompatibility antigens (mHAs), which may be disparate between the host and the recipient. ${ }^{17-20}$

Murine models suggest that aGVHD can be conceptualized as occurring in a three-step process. The first step is the release of inflammatory cytokines from tissue damaged due to the administration of high-dose chemotherapy and/or radiation therapy prior to the transplant. ${ }^{21}$ It has been postulated that the damage caused by the conditioning regimen causes inflammation leading to release of cytokines including tumor necrosis factor- $\alpha$ (TNF- $\alpha$ ) and interleukin 1 (IL-1) which in turn cause activation of host antigen-presenting cells (APCs). The second step involves the infusion of mature donor lymphocytes contained within the graft into an environment of inflammatory molecules and activated host APCs. This inflammatory environment favors expansion and activation of donor lymphocytes when contact is made with host and donor APCs expressing disparate host antigens ( $\mathrm{mHA}$ in the HLA-matched transplants). The third step is tissue damage caused by these expanded effector T-cells, which work in unison with cytokines and chemokines to further amplify the immunologic insults on the host target tissue. The degree to which step one contributes to the development of aGVHD can be debated. For instance, tissue injury is not a prerequisite for aGVHD as it may develop in situations in which conditioning is not used, such as following an infusion of donor lymphocytes or in transfusion-associated GVHD. Furthermore, the evidence is not clear that a reduction in tissue damage through the use of reduced-intensity conditioning (RIC) regimens lowers the risk for aGVHD when compared to ablative regimens. ${ }^{22,23}$ Nonetheless, the three-step model for aGVHD offers a framework for understanding the complex interactions between APCs, donor T-cells, and cytokines and the development of aGVHD.

\section{Preventative/prophylactic strategies}

Various strategies have been studied to decrease the risk of aGVHD post-transplant. The focus has been to develop 1)

Table I Classification of GVHD based on 2005 NIH consensus statement'

\begin{tabular}{llll}
\hline Classification & Timing of symptoms & Acute GVHD features & Chronic GVHD features \\
\hline Acute & & & Absent \\
Classic & $<100$ days & Present & Absent \\
Persistent/recurrent/late & $>100$ days & Present & \\
Chronic & & & Present \\
Classic & No time limit & Absent & Present \\
Overlap syndrome & No time limit & Present & \\
\hline
\end{tabular}

Abbreviations: GVHD, graft-versus-host disease; $\mathrm{NIH}$, National Institute for Health. 
better donor selection, 2) better preparative regimens, 3) T-cell depletion (TCD) from the graft, and 4) optimal pharmacologic intervention post-transplant.

\section{Donor selection}

Donor selection plays an important role in the development of aGVHD, and evaluating the risks of various donors becomes an important strategy to lessen the incidence of aGVHD. As mentioned earlier, HLA matching becomes the most important factor in determining the risk of aGVHD. It is well recognized that the incidence of aGVHD is increased in HSCT from HLA-nonidentical donors compared to HLAidentical donors. ${ }^{24} \mathrm{~A}$ higher incidence of aGVHD is also seen in unrelated HLA-matched donors compared to HLAmatched sibling donors. ${ }^{25}$ Since aGVHD occurs even in fully HLA-matched related and unrelated donors, the phenomenon is thought to be mediated by mHAs. ${ }^{17,20}$ The influence of other donor characteristics is still present, although not as important as HLA. Sex mismatching has been shown to increase aGVHD in male recipients from female donors. ${ }^{5,26}$ Women with pregnancies may be alloimmunized to the mHA from the fetus ${ }^{27}$ and mount an anamnestic response in the donor's body on recognition of overlapping mHA. Increased donor age has been shown to be a determinant of the incidence of aGVHD. ${ }^{28,29}$ The Center for International Blood and Marrow Transplant Research (CIBMTR) published an analysis in 2005, which showed an increased risk of aGVHD in ABO mismatched pairs. ${ }^{30}$ Cytomegalovirus (CMV) seronegativity of the donor has also been shown to decrease the incidence of aGVHD in seronegative recipients. ${ }^{5}$ However, in light of the limited HLA-matched donor availability, these other risk factors are of secondary importance compared to HLA matching.

\section{Conditioning regimen}

The role of preparative regimen in the development of aGVHD has been discussed earlier. Most studies have shown that increased intensity of preparative regimens also increased the risk of aGVHD. In 1990, Clift et al reported that the rate of aGVHD was lower in patients who received a lower dose of total body irradiation with similar aGVHD prophylaxis. ${ }^{31}$ Based on the preclinical murine models, RIC regimens were developed to decrease the treatment-related mortality of HSCT as well as the incidence of aGVHD. Comparisons of patients who underwent RIC versus myeloablative conditioning prior to HSCT showed $30 \%-40 \%$ relative reduction in the incidence of aGVHD for patients receiving RIC. ${ }^{32,33}$ The decision with regard to choosing between RIC and myeloablative regimens is often based on not only the risk of aGVHD but also the condition and disease of the recipient.

\section{T-cell depletion}

In 1958, Uphoff demonstrated that 'secondary disease' (a term used for GVHD) did not develop with the infusion of fetal liver/spleen tissue into lethally irradiated animals as these tissues lacked mature T-cells. ${ }^{34}$ These findings were substantiated and built upon by other researchers in the field. ${ }^{35,36}$ Subsequently, antisera against mature lymphocytes were developed and used for ex vivo TCD prior to transplantation in animal models, across histocompatibility barriers without significant GVHD. ${ }^{37,38}$ Based on these studies, clinical trials in human HSCT investigated the use of TCD using various preparations of antibodies. The initial studies with antibodies directed against T-cells alone did not reduce the risk of aGVHD in humans likely due to the fact that TCD was inadequate..$^{39,40}$ The addition of complement resulted in a 2-3 log reduction in the T-cell numbers (compared to murine antibodies alone), which decreased the incidence of aGVHD to $20 \%$ in HLA-matched sibling HSCT. ${ }^{41,42}$

Marmont et al reported outcomes on 731 patients who underwent an ex vivo TCD-related HSCT for hematologic malignancies. Although TCD decreased the rate of aGVHD (relative risk (RR): $0.45 ; P<0.0001$ ), it also increased the risk of graft failure (RR: $9.29 ; P<0.0001)$ and leukemia relapse. In patients with either first-remission acute leukemia or chronic myeloid leukemia (CML) in chronic phase, leukemia relapses were 2.75 times more likely after T celldepleted transplants $(P<0.0001)$ compared to a T-replete transplant. Overall, TCD increased the risk of treatment failure (RR: $1.35 ; P<0.0003$ ) and decreased leukemia-free survival. ${ }^{43}$ Wagner et al reported a large, randomized trial that investigated the role of ex vivo TCD in unrelated donor HSCT. Although the study showed a lower incidence of grade II-IV GVHD (39\% vs 63\%, $P<0.0001)$ in the TCD arm, there was no significant difference in overall survival. As in the previous trial, the lack of improvement in overall survival was contributed to higher relapse rates in the TCD arm for patients with CML in chronic phase. In addition, the frequency and severity of CMV and Aspergillus infections were also higher in the TCD arm. ${ }^{44}$ The Italian group reported two trials with in vivo TCD using rabbit antithymocyte globulin (Thymoglobulin). All patients received cyclosporine (CSA) and methotrexate (MTX) as GVHD prophylaxis. In the first trial, Thymoglobulin was given at a dose of $7.5 \mathrm{mg} / \mathrm{kg}$ over 2 days. The development of aGVHD, infections, and survival were similar in the Thymoglobulin group compared 
to the control group. In the second trial, Thymoglobulin was given at a dose of $15 \mathrm{mg} / \mathrm{kg}$ over 4 days. The rate of grade II-IV aGVHD was lower $(37 \%$ vs $79 \%, P=0.001)$ in the Thymoglobulin group; however, there was no difference in the treatment-related mortality due to an increase in infectious deaths in the TCD arm. No overall survival benefit was observed in these two trials. ${ }^{45}$

In a Phase III randomized trial, patients received either anti-Jurkat ATG-Fresenius ((ATG-F) $20 \mathrm{mg} / \mathrm{kg}$, given on days 3, 2, and 1 prior to transplantation) in combination with CSA and MTX; or CSA and MTX. Although the TCD treatment resulted in less overall aGVHD (grade II-IV), the rate of severe aGVHD (grade III-IV), early mortality, and overall survival were not different between the two arms. In addition, an increase in the rate of CMV and herpes simplex virus infection was noted with TCD. ${ }^{46}$

Alemtuzumab is a monoclonal antibody directed at CD52, which is a protein present at the cell surface of mature lymphocytes. It utilizes antibody-dependent cell-mediated cytotoxicity and complement fixation for cytotoxicity to lymphocytes. ${ }^{47}$ Alemtuzumab, when used in vivo before graft infusion, is highly effective with reported incidences of $20 \%$ for grade II-IV aGVHD. ${ }^{48,49}$ The use of alemtuzumab is limited by the increase in infections and relapse. However, there are no prospective, randomized trials to assess the role of alemtuzumab in prophylaxis of aGVHD. In summary, the majority of trials have shown that TCD reduces the incidence of aGVHD but often at the expense of higher relapse rates, higher graft failure rates, and higher infectious rates resulting in little impact on overall survival.

\section{Pharmacologic immunosuppression}

Historically, pharmacologic immunosuppression has been the most common approach to prevent aGVHD after allogeneic and unrelated transplantation. GVHD prophylaxis was initiated with single-agent therapy; however, randomized trials showed the advantage of using more than one agent for the prevention of aGVHD. Table 2 provides a summary of the randomized trials of various GVHD prophylactic strategies.

MTX is an antimetabolite which inhibits dihydrofolate reductase affecting purine and thymidylate synthesis. It was one of the first drugs to be tested as a prophylactic agent to prevent aGVHD, as it was thought to be cytotoxic to the rapidly proliferating activated T-cells. In addition, it was shown to induce tolerance after transplantation in matched canine models. ${ }^{50}$ MTX was used initially as a single agent for prevention of aGVHD. It was given in the intravenous formulation starting at $15 \mathrm{mg} / \mathrm{m}^{2}$ on day 1 , followed by $10 \mathrm{mg} / \mathrm{m}^{2}$ on days 3,6 , and 11 , and thereafter weekly till day $100 .{ }^{51}$ Due to the cytotoxic activity of MTX, the major toxicities were mucositis and delayed engraftment resulting in prolonged hospitalization. Deeg et al then modified the regimen to be given as $15 \mathrm{mg} / \mathrm{m}^{2}$ on day 1 , followed by $10 \mathrm{mg} / \mathrm{m}^{2}$ on days $3,6,11,18$, and 25 , and thereafter for every 2 weeks till day $100 .^{52}$

CSA was initially tested as an antifungal agent and was serendipitously found to cause immune suppression. It is thought to prevent activation of T-cells by blocking the calcium-dependent signal transduction pathway, which is activated when the $\mathrm{T}$ cell receptor is engaged. Single agent CSA was compared to MTX for the prevention of aGVHD, and studies showed no statistically significant differences in the incidence of aGVHD or overall survival between these two agents. However, the studies demonstrated shorter hospital stays and quicker engraftment in the CSA group. ${ }^{52,53}$ Additional studies comparing the two agents confirmed these results with less mucositis in the CSA group. ${ }^{54}$

In 1986, Storb et al reported the results of a randomized trial, comparing the combination of CSA and MTX versus CSA alone for the prevention of aGVHD in patients undergoing HLA-related donor HSCT for acute myeloid leukemia and CML. MTX was administered at $15 \mathrm{mg} / \mathrm{m}^{2}$ on day 1 followed by three doses of $10 \mathrm{mg} / \mathrm{m}^{2}$ given on days 3,6 , and 11 . The results showed a statistically significant benefit in favor of the combination arm for both the incidence of aGVHD (33\% vs 54\%, $P=0.014$ ) and overall survival ( $80 \%$ vs $55 \%$ at 1.5 years, $P=0.042) .{ }^{3}$ CSA was also combined with methylprednisolone (MP) and compared to single agent CSA for prevention of aGVHD. Although the trial showed statistically significant improvement in the incidence of grade II-IV aGVHD $(60 \%$ vs $73 \%, P=0.01)$ in favor of the combination arm, this trial did not demonstrate a significant improvement in overall survival. ${ }^{55}$

Tacrolimus is a macrolide antibiotic, which is extracted from a soil fungus. ${ }^{56}$ It was found to be immunosuppressive, with a mechanism of action similar to that of CSA. Based on several Phase II trials which showed efficacy of the combination of tacrolimus and MTX for the prevention of aGVHD, ${ }^{57,58}$ two large, randomized trials compared tacrolimus and MTX to CSA and MTX for the prevention of aGVHD in related and unrelated marrow transplantation. In the first trial, 329 patients undergoing HLA-matched sibling transplants received MTX on days $1,3,6$, and $11\left(15,10,10\right.$, and $10 \mathrm{mg} / \mathrm{m}^{2}$, respectively) and randomized to either CSA ( $3 \mathrm{mg} / \mathrm{kg} /$ day) or tacrolimus $(0.03 \mathrm{mg} / \mathrm{kg} /$ day $)$ starting at day 1 and tapered off by day 180 


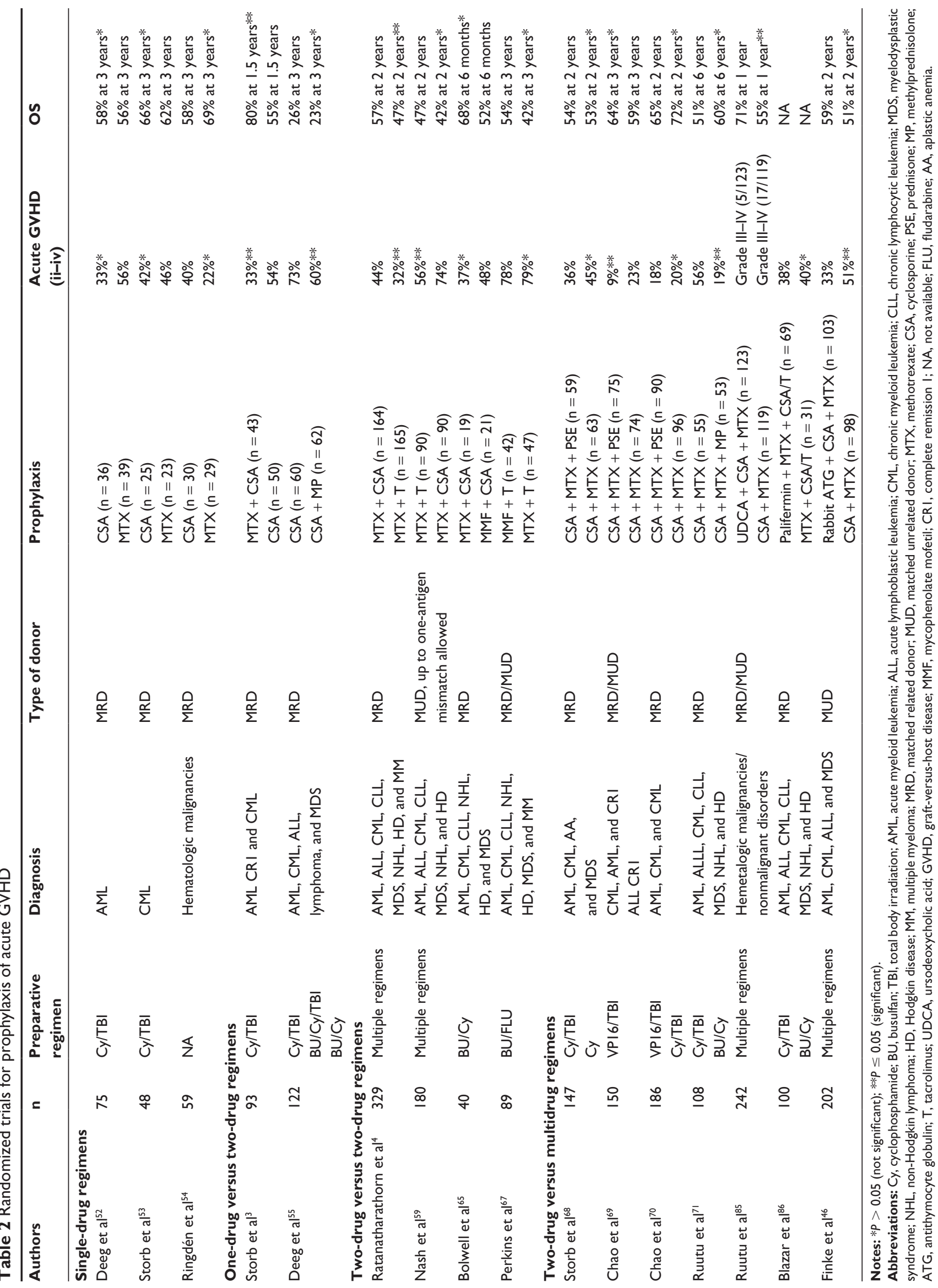


for the prevention of aGVHD. ${ }^{4}$ The incidence of aGVHD was $32 \%$ in the tacrolimus arm versus $44 \%$ in the CSA arm $(P=0.01)$. Although the overall survival was inferior in the tacrolimus arm, it appeared that this was due to a higher than expected number of patients with advanced disease in the tacrolimus arm. A companion study comparing the same regimens for aGVHD prophylaxis was performed in unrelated transplantation, and similar to the results of the study in related transplantation, the rate of aGVHD was lower in the tacrolimus and MTX arms (56\% vs 74\%, $P=0.0002)$, with no significant difference in overall survival. ${ }^{59}$

Although MTX has become a standard part of most immunosuppressive regimens for GVHD prevention, its two most common side effects, mucositis and delayed engraftment, make its use difficult. Several groups have investigated prophylactic regimens that do not contain MTX. Mycophenolate mofetil (MMF) is an antimetabolite that is hydrolyzed in the body to the active moiety mycophenolic acid. Mycophenolic acid inhibits inosine monophosphate dehydrogenase, blocking de novo purine synthesis, which results in an inhibition of both $\mathrm{T}$ - and B-cell proliferation as well as a decrease in antibody production. ${ }^{60,61}$ Dog models showed that a combination of CSA and MMF prevented graft rejection and GVHD in transplants from DLA-identical litter mates. ${ }^{62}$ Based on these preclinical models, various immunosuppressive agents have been combined with MMF for the prevention of aGVHD. Several single-center trials have reported Phase II results on the use of MMF with tacrolimus for the prevention of aGVHD. A recent study reported on 131 patients who received tacrolimus and MMF as prophylaxis for GVHD, after matched related donor (MRD) HSCT using myeloablative conditioning regimens. The cumulative incidence of grade I-IV aGVHD was $12 \%$ after 120 days. ${ }^{63}$ In a nonrandomized study, tacrolimus and MMF were used as GVHD prophylaxis following nonmyeloablative conditioning and unrelated hematopoietic HSCT for patients with advanced hematologic diseases. MMF was tapered starting at day 28 and discontinued by day 50 after transplant, while tacrolimus taper was based on disease status at transplant. This study showed delayed onset of aGVHD, with an incidence of grade II-IV aGVHD of $54 \% .{ }^{64} \mathrm{~A}$ prospective, randomized trial compared CSA/MTX and CSA/MMF in the setting of myeloablative preparative regimens followed by HLA-MRD HSCT for patients with advanced hematologic malignancies. Patients on the CSA/MMF arm showed early engraftment (day 11 vs day $18, P=0.008$ ) and less mucositis (21\% vs $65 \%, P<0.001)$ compared to CSA/MTX but no difference in the incidence of aGVHD or overall survival. ${ }^{65}$ In a retrospective analysis, CSA in combination with MMF or MTX after RIC HSCT from HLA-identical siblings showed similar incidence of grade II-IV aGVHD (48\% vs 50\%, $P=\mathrm{ns})$ with increased incidence of mucositis in the MTX $\operatorname{arm}(57 \%$ vs $23 \%, P=0.001){ }^{66}$

Perkins et al have recently reported the results of a randomized Phase II trial that compared tacrolimus in combination with MMF or MTX as prophylactic regimens for related and unrelated transplantation in 89 patients. The incidence of aGVHD was $78 \%$ in the $\mathrm{MMF} /$ tacrolimus arm compared to $79 \%$ in the MTX/tacrolimus arm $(P=0.8)$. There was no difference in overall survival. The study also showed shorter hospital stays and less mucositis in patients who received MMF. ${ }^{67}$ However, patients who received the $\mathrm{MMF} /$ tacrolimus combination had a higher rate of severe grade III-IV aGVHD (26\% vs $4 \%, P=0.04)$ in unrelated donors, suggesting this combination may not be adequate in unrelated transplantation.

The use of three drugs for the prevention of aGVHD has also been investigated. Storb et al reported a trial with 147 patients who received GVHD prophylaxis with the combination of CSA, MTX, and prednisone (MP) or CSA and MTX. The incidence of aGVHD was not decreased by the addition of prednisone, and overall survival was similar in the two groups. ${ }^{68}$

In another randomized trial, Chao et al also compared the incidence of aGVHD in patients undergoing allogeneic transplant, who received either CSA and MTX; or CSA, MTX, and prednisone. ${ }^{69}$ They found there was a significantly lower incidence of aGVHD in the group receiving CSA, MTX, and prednisone $(9 \%)$ compared to the group receiving CSA and MTX $(23 \%)(P=0.02)$. However, there was no difference in disease-free survival between the two groups at 3 years. Subsequently, when the same regimen was studied in patients with advanced hematologic malignancies, no difference in the incidence of aGVHD was seen between the three-drug and two-drug regimen ( $18 \%$ and $20 \%, P=0.6){ }^{70}$

Ruutu et al used CSA and MTX with and without MP for GVHD prophylaxis in a prospective, randomized trial with 108 patients. Steroids were initiated at day 14 at a dose of $0.5 \mathrm{mg} / \mathrm{kg}$, then increased to $1 \mathrm{mg} / \mathrm{kg}$ at days $21-34$, and subsequently tapered. Initiation of steroids at day 14 was chosen to eliminate the potential interaction with MTX. Despite a significantly lower incidence of aGVHD (19\% vs $56 \%, P=0.0001)$, the study failed to show any survival benefit for the MP arm. ${ }^{71}$ 
Sirolimus is another macrolide, which was shown to have immunosuppressive activity. Structurally, sirolimus is similar to tacrolimus, containing a hemiketal-masked $\alpha \beta$-diketopipecolic acid amidic component. ${ }^{72}$ Sirolimus has been shown to inhibit cytokine-driven growth of lymphoid cells ${ }^{73}$ decrease production of interferon $\gamma\left(\right.$ IFN- $\gamma$ ) ${ }^{74}$ downregulate CD28, ${ }^{75}$ and increase regulatory T-cells. ${ }^{76}$ Sirolimus was initially added to tacrolimus and MTX for the prevention of aGVHD. In a Phase II trial, 39 patients undergoing an allogeneic HSCT from mismatched related or unrelated donors after a myeloablative preparatory regimen received a combination of tacrolimus, sirolimus, and MTX. The incidence of grade II-IV aGVHD was $26 \% .^{77}$ In a larger study of 91 patients who underwent HSCT from MRDs or MUDs with RIC regimen, the cumulative incidence of a grade II-IV aGVHD was $16 \%{ }^{78}$

In the setting of RIC regimen, Ho et al combined sirolimus and tacrolimus and reported an incidence of aGVHD of $17 \%$. The incidence was felt to be similar to a three-drug prophylactic regimen of tacrolimus/sirolimus/MTX (11\%) used by the same group in a previous study. ${ }^{79} \mathrm{~A}$ Phase II study of tacrolimus/sirolimus GVHD prophylaxis for MRD HSCT using different myeloablative conditioning regimens in 85 patients showed a cumulative incidence of aGVHD (grade II-IV) of $43 \% .{ }^{80}$ Others have shown similar efficacy with the combination of sirolimus and tacrolimus. Cutler et al reported on the incidence of aGVHD in 83 patients who received either related or unrelated transplants using sirolimus and tacrolimus. ${ }^{81}$ The cumulative incidence of grade II-IV and III-IV aGVHD was $20.5 \%$ and $4.8 \%$, respectively. They also indicated that the omission of MTX was associated with low transplant-related toxicity and an excellent 100-day survival rate of $95.2 \%$. No differences in the aGVHD rate were noted between related and unrelated transplant patients. The same group also reported that sirolimus may lead to a higher than expected rate of venoocclusive disease when used with some of the more intense preparative regimens. ${ }^{82}$

Extracorporeal photopheresis (ECP) has recently been reported to be a strategy for prevention of aGVHD. The mechanism of action of ECP is not clear, although it may decrease $\mathrm{CD} 8+$ cytotoxic T-cells and increase regulatory T-cells. ${ }^{83}$ Sixty-two patients, 31 (6/6 matched unrelated donor (MUD)), 30 (6/6 MRD), and 1 (5/6 MRD), underwent two rounds of ECP within 4 days of starting the preparative regimen. All patients received prophylaxis with CSA and MTX in addition to the ECP. The cumulative incidence of
aGVHD was $30 \%$ in MRD HSCT and $41 \%$ in MUD HSCT. ${ }^{84}$ ECP is being further investigated currently in a randomized Phase II study.

\section{Other interventions}

Several strategies involving organ protection have been studied to reduce the incidence of aGVHD. The Nordic group reported a prospective, randomized trial on the addition of ursodeoxycholic acid (UDCA) to their standard prophylactic regimen of CSA and MTX. UDCA was administered from the start of the conditioning regimen until day 90 posttransplant. Patients who received UDCA had a significantly lower incidence of severe grade III-IV aGVHD $(P=0.01)$ and showed significant improvement in overall survival at 1 year $(71 \%$ vs $55 \%, P=0.01) .{ }^{85}$ The improvement seen with the use of UDCA may be due to reducing the expression of various antigens involved in aGVHD.

As mentioned earlier, animal models suggested gastrointestinal (GI) injury may be the first step in the pathophysiology of aGVHD. Based on these data, the effect of keratinocyte growth factor (KGF) was studied in a Phase I/II placebocontrolled trial for the prevention of aGVHD. KGF is an epithelial growth factor which has demonstrated efficacy in the prevention of chemo or radiation injury to various epithelial cells. Although the administration of KGF was safe, it had no significant benefit when added to MTX and CSA or MTX and tacrolimus for the prevention of aGVHD. ${ }^{86}$

\section{Treatment strategies Primary therapy for aGVHD}

Despite the various prophylactic measures used to prevent aGVHD, its incidence remains high occurring in $40 \%-60 \%$ of the patients undergoing HSCT. Corticosteroids have been the mainstay in treatment of aGVHD and are used in IV, oral, and topical formulations depending upon the severity and organ involvement. Randomized studies evaluating different agents for primary treatment of aGVHD are summarized in Table 3 .

For isolated skin GVHD up to stage $2(<50 \%$ involvement of skin with maculo-papular rash), treatment with topical steroids is acceptable. The recommended dose of systemic steroids for grade II-IV disease is $2 \mathrm{mg} / \mathrm{kg} /$ day of MP. Higher doses of steroid provide no further benefit as shown in a randomized trial comparing $2 \mathrm{mg} / \mathrm{kg} /$ day versus $10 \mathrm{mg} / \mathrm{kg} /$ day for treatment of aGVHD. ${ }^{87}$ Hings et al randomized patients to long versus short taper of steroids after response to $2 \mathrm{mg} / \mathrm{kg}$ /day of MP on day 14 of treatment. The patients on long taper were on MP for median of 147 days, 
Table 3 Randomized trials for up-front treatment of aGVHD

\begin{tabular}{|c|c|c|c|c|c|c|c|c|}
\hline \multirow[t]{2}{*}{ Authors } & \multirow[t]{2}{*}{$\mathbf{n}$} & \multirow[t]{2}{*}{ Treatment } & \multicolumn{4}{|c|}{ aGVHD grade } & \multirow{2}{*}{$\begin{array}{l}\text { Overall response } \\
\text { rate }(C R+P R)\end{array}$} & \multirow{2}{*}{$\begin{array}{l}\text { Overall } \\
\text { survival }\end{array}$} \\
\hline & & & $I$ & II & III & IV & & \\
\hline \multirow[t]{2}{*}{ Cragg et al ${ }^{2}$} & 96 & $\begin{array}{l}\text { Prednisone }\left(60 \mathrm{mg} / \mathrm{m}^{2}\right) \\
(\mathrm{n}=46)\end{array}$ & $22 \%$ & $74 \%$ & $4 \%$ & 0 & 73\% (grade II-IV) & $50 \%$ at 2 years \\
\hline & & $\begin{array}{l}\text { ATG }\left(15 \mathrm{mg} / \mathrm{m}^{2} \mathrm{bid}\right)+ \\
\text { prednisone }\left(20 \mathrm{mg} / \mathrm{m}^{2}\right) \\
(\mathrm{n}=50)\end{array}$ & $24 \%$ & $70 \%$ & $6 \%$ & 0 & $78 \%$ (grade II-IV)* & $40 \%$ at 2 years* \\
\hline \multirow[t]{2}{*}{ Van Lint et $\mathrm{a}^{87}$} & 95 & $\begin{array}{l}\text { MP } 2 \mathrm{mg} / \mathrm{kg} \\
(\mathrm{n}=47)\end{array}$ & NA & NA & NA & NA & $68 \%$ & $63 \%$ at 3 years \\
\hline & & $\begin{array}{l}M P 10 \mathrm{mg} / \mathrm{kg} \\
(\mathrm{n}=48)\end{array}$ & NA & NA & NA & NA & $70 \% *$ & $62 \%$ at 3 years $*$ \\
\hline \multirow[t]{2}{*}{ Lee et $\mathrm{a}^{90}$} & 102 & $\begin{array}{l}\mathrm{MP}(2 \mathrm{mg} / \mathrm{kg}) \\
(\mathrm{n}=49)\end{array}$ & $20 \%$ & $55 \%$ & $25 \%$ & & $53 \%$ & $60 \%$ at I year \\
\hline & & $\begin{array}{l}\text { Daclizumab + MP }(2 \mathrm{mg} / \mathrm{kg}) \\
(\mathrm{n}=53)\end{array}$ & $21 \%$ & $64 \%$ & $15 \%$ & & $51 \% *$ & $26 \%$ at I year** \\
\hline \multirow[t]{2}{*}{ Couriel et $\mathrm{a}^{91}$} & 59 & $\begin{array}{l}\mathrm{MP}(2 \mathrm{mg} / \mathrm{kg}) \\
(\mathrm{n}=28)\end{array}$ & 0 & $68 \%$ & $32 \%$ & 0 & $54 \%$ & $28 \%$ at 5 years \\
\hline & & $\begin{array}{l}\text { MP }(2 \mathrm{mg} / \mathrm{kg})+\text { infliximab } \\
(10 \mathrm{mg} / \mathrm{kg}) \\
(\mathrm{n}=29)\end{array}$ & 0 & $65 \%$ & $31 \%$ & $3 \%$ & $30 \% *$ & $17 \%$ at 5 years* \\
\hline \multirow[t]{4}{*}{ Alousi et $\mathrm{a}^{92}$} & 180 & $\begin{array}{l}\text { Etanercept }+ \text { MP }(2 \mathrm{mg} / \mathrm{kg}) \\
(\mathrm{n}=46)\end{array}$ & 17 & 54 & 26 & 0 & $26 \%(C R)$ & $47 \%$ at 9 months \\
\hline & & $\begin{array}{l}M M F+M P(2 \mathrm{mg} / \mathrm{kg}) \\
(\mathrm{n}=45)\end{array}$ & 7 & 56 & 36 & 2 & $60 \%(C R)$ & $64 \%$ at 9 months \\
\hline & & $\begin{array}{l}\text { Denileukin + MP (2 mg/kg) } \\
(\mathrm{n}=47)\end{array}$ & 17 & 49 & 32 & 2 & $53 \%(C R)$ & $49 \%$ at 9 months \\
\hline & & $\begin{array}{l}\text { Pentostatin + MP }(2 \mathrm{mg} / \mathrm{kg}) \\
(\mathrm{n}=42)\end{array}$ & 10 & 62 & 26 & 2 & $38 \%(C R)$ & $47 \%$ at 9 months \\
\hline
\end{tabular}

Notes: $* P>0.05$ (not significant); $* * P \leq 0.05$ (significant).

Abbreviations: MP, methylprednisolone; ATG, antithymocyte globulin; MMF, mycophenolate mofetil; NA, not available; aGVHD, acute graft-versus-host disease; PR, partial remission; $\mathrm{CR}$, complete remission.

while those on short taper were on MP for median of 86 days. This trial did not show any difference in overall survival for both the groups. ${ }^{88}$

Although steroids have become the standard of care for the treatment of aGVHD, their effectiveness remains suboptimal. Two large, retrospective studies on the use of steroids for the primary treatment of aGVHD reported sustained complete remission (CR) rates of only $18 \%$ and $35 \%$.,89

Due to the poor overall response rates, several groups have looked at intensifying the immunosuppressive regimen by adding additional agents to steroids for the initial treatment of aGVHD. Daclizumab was studied by Lee et al in a randomized trial comparing steroids versus steroids plus daclizumab for the initial treatment of aGVHD. The trial enrolled 102 patients from 5 institutions..$^{90}$ Patients on the trial received HSCT from MRDs (40\%) or MUDs (40\%), with a minority of the patients on each arm receiving mismatched related/unrelated HSCT. The response rate was $53 \%$ in the steroid arm, compared to $51 \%$ in patients who received the combination of steroids and daclizumab $(P=0.85)$. The 100 -day survival was worse in the combination arm $(77 \%$ vs $94 \%, P=0.02)$.

Infliximab was tested in a randomized Phase III trial as up-front treatment of aGVHD. ${ }^{91}$ A total of 63 patients were randomized to either infliximab and MP ( $2 \mathrm{mg} / \mathrm{kg} /$ day $)$ or MP ( $2 \mathrm{mg} / \mathrm{kg} /$ day). Sixty-seven percent of patients had grade II and $33 \%$ had grade III-IV aGVHD. At day 28, the response rate for infliximab $+\mathrm{MP}$ was $62 \%$, while the response rate for MP was 58\% $(P=0.7)$. Cumulative incidences of nonrelapse mortality and overall survival were not significantly different between the two groups.

A randomized trial of 96 patients evaluated the combination of steroids and ATG compared to steroids alone as initial therapy of aGVHD. ${ }^{2}$ This trial showed partial and complete response rates of $76 \%$ patients in both the arms $(P>0.8)$. Complications with CMV reactivation and pneumonitis (both infectious and noninfectious) were higher in the ATG arm, with no significant difference in overall survival at 2 years.

Alousi et al, ${ }^{92}$ on behalf of Bone Marrow Transplant Clinical Trials Network, investigated the role of etanercept, ${ }^{93}$ 
mycophenolate, ${ }^{94}$ denileukin,${ }^{95}$ or pentostatin ${ }^{96}$ plus corticosteroids for initial treatment of aGVHD. In this randomized Phase II trial, the day 28 complete response rates were $60 \%, 53 \%, 38 \%$, and $26 \%$ for MMF, denileukin, pentostatin, and etanercept, respectively, suggesting the combination of steroids and MMF provides the best combination for treatment of aGVHD. A randomized Phase III trial which will compare $\mathrm{MMF} /$ steroids with steroids alone is ongoing. In summary, the trials to date have not shown benefit when further immunosuppressive agents are added to steroids for the treatment of aGVHD.

\section{Secondary therapy for aGVHD/steroid- refractory aGVHD}

Criteria for diagnosing steroid refractoriness have not been formalized, but the study by Van Lint et al suggests that no response by day 5 of treatment with steroids is a reliable marker of poor outcome; patients who respond to $2 \mathrm{mg} / \mathrm{kg} /$ day of steroids by day 5 had a nonrelapse mortality of $27 \%$, compared to a $49 \%$ nonrelapse mortality for day- 5 nonresponders. ${ }^{97}$ Unfortunately, there are no proven treatments based on Phase III trials for steroid-refractory GVHD. The bulk of the data from treatment of these patients often rely on small Phase II trials with different eligibility criteria making comparisons and treatment decisions difficult. The choice of secondary therapy is often based on pre-existing organ toxicity and prior GVHD prophylaxis of the patient.

\section{Antithymocyte globulin}

ATG is the most common treatment of choice for steroid-refractory aGVHD based on an international practice survey by Hsu et al. ${ }^{98}$ ATG has been shown to increase regulatory T-cells which have an important role in the development of tolerance. ${ }^{99}$

There are various ATG preparations (rabbit vs horse) with differing potency and different treatment regimens making comparisons between studies difficult. Arai et al retrospectively reviewed 69 patients who were treated with ATG for steroid-refractory aGVHD. ${ }^{100}$ The criteria for adding ATG varied. In some patients, ATG was added when patients were refractory to frontline treatment. In other patients, ATG was administered during flares of aGVHD, which did not respond to reescalation of steroids. Patients received a total of seven doses of horse ATG of $10-15 \mathrm{mg} / \mathrm{kg}$ every other day. The overall response rate with ATG salvage, which included partial and complete response, was $42 \%$ and $24 \%$ for grade II and grade III-IV GVHD, respectively.
MacMillan et al retrospectively analyzed data from 79 patients treated at their institution with horse ATG $(15 \mathrm{mg} / \mathrm{kg}$, twice a day for 5 days). ${ }^{101}$ Steroid-refractory aGVHD was defined as worsening of GVHD within 4 days of initiation of steroids or failure to respond by 7 days of treatment with steroids. The overall response rate of day 28 was $54 \%(20 \% \mathrm{CR}+34 \%$ partial remission (PR)). Based on these and other studies, $20 \%-50 \%$ of patients will improve on ATG but responses appear most common with steroid-refractory skin GVHD as $60 \%-75 \%$ of these patients respond. ${ }^{102}$ The main complications from therapy with ATG are related to infusion reactions and increased risk of viral and fungal infections.

\section{Biological therapies}

Various antibodies have been studied for treatment of aGVHD including antibodies directed at T-cells (antiCD2, anti-CD3, anti-CD5, anti-CD25, anti-CD 52, and anti-CD147) and inflammatory cytokines (etanercept and infliximab).

BTI-322, a rat monoclonal IgG2b directed against the CD2 antigen on T-cells and natural killer cells, blocks primary and memory alloantigen proliferative responses in vitro. It was tested in 20 patients with steroid-refractory $\mathrm{aGVHD}$ and showed a response rate of $55 \%{ }^{103}$ OKT3 is a murine monoclonal antibody directed at CD3. When OKT3 was added to MP, there was an observed response rate of $53 \%$ compared to a $33 \%$ response in the control arm that used steroids alone. The difference was not statistically significant, and the dose of MP (10 mg/kg) was high. ${ }^{104}$ Several complications were seen with the use of OKT3 including higher risk of viral infections, especially Epstein-Barr virus (EBV), and a higher incidence of cytokine storm due to TNF- $\alpha{ }^{105}$ Visilizumab, an antibody directed at CD3 that does not bind to human Fc receptor, showed a response rate of $32 \%$ in steroid-refractory aGVHD. EBV reactivation occurred in 19/44 patients treated on the protocol. ${ }^{106}$

Anti-CD5 antibody conjugated with ricin cytotoxin has been studied in a Phase I-II trial with 34 patients. Response rate of skin, GI, and liver GVHD were $73 \%, 45 \%$, and $28 \%$, respectively. ${ }^{107}$

Activated $\mathrm{T}$ cell can be targeted by antibodies directed at CD25 ( $\alpha$-subunit of IL-2 receptor). Daclizumab, Inolimomab, basiliximab, and denileukin diftitox have been used to target activated T-cells to elicit a response in refractory GVHD. The use of daclizumab was reported to show improvement in $30 \%-50 \%$ of patients with steroid-refractory GVHD but came with a risk of increased infectious 
complications. ${ }^{108-110}$ Inolimomab (murine IL-2 receptor antibody) showed a response rate of $63 \%$ in steroid-refractory aGVHD. ${ }^{111}$ Basilixumab (chimeric IL-2 receptor antibody) was shown to have an impressive $71 \%$ response rate in steroid-refractory aGVHD; ${ }^{112}$ a later trial with 34 patients demonstrated overall response rates of $26 \%, 48 \%$, and $84 \%$ in liver, GI, and skin GVHD, respectively. ${ }^{113}$ Denileukin diftitox, a recombinant fusion protein which contains parts of IL-2 and diphtheria toxin amino acid sequence, showed a $71 \%$ response rate in steroid-refractory aGVHD in a Phase I trial. ${ }^{95}$ Alemtuzumab was evaluated in a Phase II setting for 10 patients with steroid-refractory aGVHD and showed a clinical response rate of $55 \%$, with complete resolution seen only in two patients. ${ }^{114} \mathrm{ABX}-\mathrm{CBL}$ is a murine antibody directed at CD147. It was tested in a randomized trial against ATG, and similar response rates were observed for the two agents (56\% vs 57\%, $P=0.91)$. However, the survival rate of patients treated with ABX-CBL was inferior, although not achieving statistical significance ( $35 \%$ vs $45 \%, P=0.1) .{ }^{115}$

Based on murine data that showed inflammatory cytokines such as TNF- $\alpha$ are important in the pathophysiology of aGVHD, various studies testing antibodies against these inflammatory molecules have been reported. The use of etanercept (fusion protein capable of neutralizing TNF- $\alpha$ ) combined with steroids was reported to have a $75 \%$ complete response rate for up-front treatment of aGVHD. ${ }^{93}$ Busca et al studied this drug in steroid-refractory GVHD and obtained responses in $46 \%$ of the patients. ${ }^{116}$ Infliximab is a chimeric antibody directed against TNF- $\alpha$, which was reported to have activity (response rates of $60 \%$ ) in steroidrefractory GVHD, especially with the involvement of the GI tract. ${ }^{117}$ However, when both of these anti-TNF compounds were tested in larger separate trials, their efficacy was somewhat lower. ${ }^{91,92}$

\section{Extracorporeal photopheresis}

Several studies have now shown that ECP may play a role in treatment of aGVHD. In a pilot trial of 21 patients with steroid-refractory aGVHD, 60\% responded to ECP. However, none of the patients with GI GVHD responded to this intervention. ${ }^{118}$ Greinix et al, in 2006, reported the results of a Phase II trial of 59 patients with steroidrefractory aGVHD treated with ECP. They had a complete response rate of $82 \%, 61 \%$, and $61 \%$ in patients with skin, liver, and GI GVHD, respectively. ${ }^{119}$ A review, published in 2002, summarized the results on the use of ECP in aGVHD in 76 patients treated in 11 separate studies. ${ }^{120}$ Of the 76 patients, 59, 47, and 28 presented with skin, liver, and GI manifestations of aGVHD, respectively. Treatment duration ranged from 1 to 24 months. Regression of skin manifestations was observed in $83 \%$ of the patients with a complete response in $67 \%$. A complete regression of liver and gut manifestations was reported in $38 \%$ and $54 \%$ of the patients, respectively.

\section{Mesenchymal stem cells}

Bone marrow-derived mesenchymal stem cells (MSCs) have been shown in animal models and in vitro testing to modulate immune and inflammatory responses and facilitate repair of connective tissue. In addition, they inhibit inflammatory cytokines, such as TNF- $\alpha$ and IFN- $\gamma$. These experimental data supported the concept of MSCs as therapeutically effective cells for treatment of aGVHD. Leblanc et al treated 55 patients with MSCs for steroid-refractory aGVHD and showed responses in $55 \% .{ }^{121}$ A response rate of $15 \%$ was reported by Von Bonin et al after utilizing MSCs for steroidrefractory aGVHD. ${ }^{122}$ Kebriaei et al, in a small Phase II trial, reported on the safety and efficacy of a commercially available preparation of unrelated human MSCs formulated for IV delivery in patients with aGVHD. ${ }^{123}$ Patients were given MSCs along with steroids with the onset of aGVHD. They reported that the cells could be administered safely, and $77 \%$ of patients had an initial CR to therapy. Given the safety and initial efficacy, these cells were then tested in a randomized placebo-controlled Phase III trial in steroidrefractory aGVHD. In spite of the initial reports, there was no statistical advantage in response rates or overall survival in patients who received the MSC preparation. ${ }^{124}$

\section{Summary}

It is clear that outcomes of transplantation have improved markedly. Improvements have been due to many factors including better supportive care, high-resolution HLA typing that leads to better donor matching, and the increased use of reduced-intensity transplant regimens. However, aGVHD remains a major complication when using this procedure and continues to play a role in the morbidity and mortality associated with it. To expand the use of allogeneic transplant, better management strategies for the prevention and treatment of aGVHD are needed. Although many agents have been studied, few have shown promise in treating aGVHD. Certainly, more clinical trials are needed to better define options for the prevention and treatment of aGVHD.

\section{Disclosure}

The authors report no conflicts of interest in this work. 


\section{References}

1. Filipovich AH, Weisdorf D, Pavletic S, et al. National Institutes of Health consensus development project on criteria for clinical trials in chronic graft-versus-host disease: I. Diagnosis and staging working group report. Biol Blood Marrow Transplant. 2005;11(12):945-956.

2. Cragg L, Blazar BR, Defor T, et al. A randomized trial comparing prednisone with antithymocyte globulin/prednisone as an initial systemic therapy for moderately severe acute graft-versus-host disease. Biol Blood Marrow Transplant. 2000;6(4A):441-447.

3. Storb R, Deeg HJ, Whitehead J, et al. Methotrexate and cyclosporine compared with cyclosporine alone for prophylaxis of acute graft versus host disease after marrow transplantation for leukemia. $N$ Engl J Med. 1986;314(12):729-735.

4. Ratanatharathorn V, Nash RA, Przepiorka D, et al. Phase III study comparing methotrexate and tacrolimus (prograf, FK506) with methotrexate and cyclosporine for graft-versus-host disease prophylaxis after HLA-identical sibling bone marrow transplantation. Blood. 1998;92(7):2303-2314.

5. Weisdorf D, Hakke R, Blazar B, et al. Risk factors for acute graft-versushost disease in histocompatible donor bone marrow transplantation. Transplantation. 1991;51(6):1197-1203.

6. Martin PJ, Schoch G, Fisher L, et al. A retrospective analysis of therapy for acute graft-versus-host disease: initial treatment. Blood. 1990;76(8):1464-1472.

7. Mielcarek M, Storb R. Graft-vs-host disease after non-myeloablative hematopoietic cell transplantation. Leuk Lymphoma. 2005;46(9): 1251-1260.

8. Flomenberg N, Baxter-Lowe LA, Confer D, et al. Impact of HLA class I and class II high-resolution matching on outcomes of unrelated donor bone marrow transplantation: HLA-C mismatching is associated with a strong adverse effect on transplantation outcome. Blood. 2004;104(7):1923-1930.

9. Bensinger W; Stem Cell Trialists' Collaborative Group. Individual patient data meta-analysis of allogeneic peripheral blood stem cell transplant vs bone marrow transplant in the management of hematological malignancies: indirect assessment of the effect of day 11 methotrexate administration. Bone Marrow Transplant. 2006;38(8):539-546.

10. Blaise D, Kuentz M, Fortanier C, et al. Randomized trial of bone marrow versus lenograstim-primed blood cell allogeneic transplantation in patients with early-stage leukemia: a report from the Societe Francaise de Greffe de Moelle. J Clin Oncol. 2000;18(3):537-546.

11. Couban S, Simpson DR, Barnett MJ, et al; Canadian Bone Marrow Transplant Group. A randomized multicenter comparison of bone marrow and peripheral blood in recipients of matched sibling allogeneic transplants for myeloid malignancies. Blood. 2002;100(5):1525-1531.

12. Schmitz N, Beksac M, Hasenclever D, et al; European Group for Blood and Marrow Transplantation. Transplantation of mobilized peripheral blood cells to HLA-identical siblings with standard-risk leukemia. Blood. 2002;100(3):761-767.

13. Billingham RE. The biology of graft-versus-host reactions. Harvey Lect. 1966;62:21-78.

14. Prasad VK, Kernan NA, Heller G, O’Reilly RJ, Yang SY. DNA typing for HLA-A and HLA-B identifies disparities between patients and unrelated donors matched by HLA-A and HLA-B serology and HLADRB1. Blood. 1999;93(1):399-409.

15. Van Heeckeren WJ, Fanning LR, Meyerson HJ, et al. Influence of human leucocyte antigen disparity and graft lymphocytes on allogeneic engraftment and survival after umbilical cord blood transplant in adults. Br J Haematol. 2007;139(3):464-474.

16. Ferrara GB, Bacigalupo A, Lamparelli T, et al. Bone marrow transplantation from unrelated donors: the impact of mismatches with substitutions at position 116 of the human leukocyte antigen class I heavy chain. Blood. 2001;98(10):3150-3155.

17. Den Haan JM, Sherman NE, Blokland E, et al. Identification of a graft versus host disease-associated human minor histocompatibility antigen. Science. 1995;268(5216):1476-1480.
18. Gale RP, Bortin MM, van Bekkum DW, et al. Risk factors for acute graft-versus-host disease. Br J Haematol. 1987;67(4):397-406.

19. Hahn T, McCarthy PL Jr, Zhang MJ, et al. Risk factors for acute graft-versus-host disease after human leukocyte antigenidentical sibling transplants for adults with leukemia. J Clin Oncol. 2008;26(35):5728-5734.

20. Goulmy E, Schipper R, Pool J, et al. Mismatches of minor histocompatibility antigens between HLA-identical donors and recipients and the development of graft-versus-host disease after bone marrow transplantation. N Engl J Med. 1996;334(5):281-285.

21. Ferrara JL, Reddy P. Pathophysiology of graft-versus-host disease. Semin Hematol. 2006;43(1):3-10.

22. Couriel DR, Saliba RM, Giralt S, et al. Acute and chronic graft-versushost disease after ablative and nonmyeloablative conditioning for allogeneic hematopoietic transplantation. Biol Blood Marrow Transplant. 2004;10(3):178-185.

23. Mielcarek M, Martin PJ, Leisenring W, et al. Graft-versus-host disease after nonmyeloablative versus conventional hematopoietic stem cell transplantation. Blood. 2003;102(2):756-762.

24. Beatty PG, Clift RA, Mickelson EM, et al. Marrow transplantation from related donors other than HLA-identical siblings. $N$ Engl J Med. 1985;313(13):765-771.

25. Kernan NA, Bartsch G, Ash RC, et al. Analysis of 462 transplantations from unrelated donors facilitated by the National Marrow Donor Program. N Engl J Med. 1993;328(9):593-602.

26. Bross DS, Tutschka PJ, Farmer ER, et al. Predictive factors for acute graft-versus-host disease in patients transplanted with HLA-identical bone marrow. Blood. 1984;63(6):1265-1270.

27. Flowers ME, Pepe MS, Longton G, et al. Previous donor pregnancy as a risk factor for acute graft-versus-host disease in patients with aplastic anaemia treated by allogeneic marrow transplantation. Br J Haematol. 1990;74(4):492-496.

28. Nash RA, Pepe MS, Storb R, et al. Acute graft-versus-host disease: analysis of risk factors after allogeneic marrow transplantation and prophylaxis with cyclosporine and methotrexate. Blood. 1992;80(7):1838-1845.

29. Eisner MD, August CS. Impact of donor and recipient characteristics on the development of acute and chronic graft-versus-host disease following pediatric bone marrow transplantation. Bone Marrow Transplant. 1995;15(5):663-668.

30. Seebach JD, Stussi G, Passweg JR, et al; GVHD Working Committee of Center for International Blood and Marrow Transplant Research. $\mathrm{ABO}$ blood group barrier in allogeneic bone marrow transplantation revisited. Biol Blood Marrow Transplant. 2005;11(12):1006-1013.

31. Clift RA, Buckner CD, Appelbaum FR, et al. Allogeneic marrow transplantation in patients with acute myeloid leukemia in first remission: a randomized trial of two irradiation regimens. Blood. 1990; 76(9):1867-1871.

32. Perez-Simon JA, Diez-Campelo M, Martino R, et al. Influence of the intensity of the conditioning regimen on the characteristics of acute and chronic graft-versus-host disease after allogeneic transplantation. Br J Haematol. 2005;130(3):394-403.

33. Aoudjhane M, Labopin M, Gorin NC, et al; Acute Leukemia Working Party (ALWP) of the European group for Blood and Marrow Transplantation (EBMT). Comparative outcome of reduced intensity and myeloablative conditioning regimen in HLA identical sibling allogeneic haematopoietic stem cell transplantation for patients older than 50 years of age with acute myeloblastic leukaemia: a retrospective survey from the Acute Leukemia Working Party (ALWP) of the European group for Blood and Marrow Transplantation (EBMT). Leukemia. 2005;19(12):2304-2312.

34. Uphoff DE. Perclusion of secondary phase of irradiation syndrome by inoculation of fetal hematopoietic tissue following lethal total-body X-irradiation. J Natl Cancer Inst. 1958;20(3):625-632.

35. Reisner Y, Itzicovitch L, Meshorer A, Sharon N. Hemopoietic stem cell transplantation using mouse bone marrow and spleen cells fractionated by lectins. Proc Natl Acad Sci U S A. 1978;75(6):2933-2936. 
36. Dicke KA, Tridente G, van Bekkum DW. The selective elimination of immunologically competent cells from bone marrow and lymphocyte cell mixtures. 3. In vitro test for detection of immunocompetent cells in fractionated mouse spleen cell suspensions and primate bone marrow suspensions. Transplantation. 1969;8(4):422-434.

37. Rodt H, Kolb HJ, Netzel B, et al. GVHD suppression by incubation of bone marrow grafts with anti-T-cell globulin: effect in the canine model and application to clinical bone marrow transplantation. Transplant Proc. 1979;11(1):962-966.

38. Trentin JJ, Judd KP. Prevention of acute graft-versus-host (GVH) mortality with spleen-absorbed antithymocyte globulin (ATG). Transplant Proc. 1973;5(1):865-868.

39. Filipovich AH, McGlave P, Ramsay NK, Goldstein G, Kersey JH. Treatment of donor bone marrow with OKT3 (PAN-T monoclonal antibody) for prophylaxis of graft-vs-host disease (GvHD) in histocompatible allogeneic bone marrow transplantation (BMT): a pilot study. $J$ Clin Immunol. 1982;2(3 Suppl):154S-157S.

40. Martin PJ, Hansen JA, Thomas ED. Preincubation of donor bone marrow cells with a combination of murine monoclonal anti-T-cell antibodies without complement does not prevent graft-versus-host disease after allogeneic marrow transplantation. J Clin Immunol. 1984;4(1):18-22.

41. Trigg ME, Billing R, Sondel PM, et al. Clinical trial depleting $\mathrm{T}$ lymphocytes from donor marrow for matched and mismatched allogeneic bone marrow transplants. Cancer Treat Rep. 1985; 69(4): 377-386.

42. Herve P, Flesch M, Cahn JY, et al. Removal of marrow T cells with OKT3-OKT11 monoclonal antibodies and complement to prevent acute graft-versus-host disease. A pilot study in ten patients. Transplantation. 1985;39(2):138-143.

43. Marmont AM, Horowitz MM, Gale RP, et al. T-cell depletion of HLAidentical transplants in leukemia. Blood. 1991;78(8):2120-2130.

44. Wagner JE, Thompson JS, Carter SL, Kernan NA; Unrelated Donor Marrow Transplantation Trial. Effect of graft-versus-host disease prophylaxis on 3-year disease-free survival in recipients of unrelated donor bone marrow (T-cell Depletion Trial): a multi-centre, randomised phase II-III trial. Lancet. 2005;366(9487):733-741.

45. Bacigalupo A, Lamparelli T, Bruzzi P, et al. Antithymocyte globulin for graft-versus-host disease prophylaxis in transplants from unrelated donors: 2 randomized studies from Gruppo Italiano Trapianti Midollo Osseo (GITMO). Blood. 2001;98(10):2942-2947.

46. Finke J, Bethge WA, Schmoor C, et al; ATG-Fresenius Trial Group. Standard graft-versus-host disease prophylaxis with or without antiT-cell globulin in haematopoietic cell transplantation from matched unrelated donors: a randomised, open-label, multicentre phase 3 trial. Lancet Oncol. 2009;10(9):855-864.

47. Hale G, Bright $\mathrm{S}$, Chumbley G, et al. Removal of $\mathrm{T}$ cells from bone marrow for transplantation: a monoclonal antilymphocyte antibody that fixes human complement. Blood. 1983;62(4):873-882.

48. Chakraverty R, Peggs K, Chopra R, et al. Limiting transplantationrelated mortality following unrelated donor stem cell transplantation by using a nonmyeloablative conditioning regimen. Blood. 2002;99(3):1071-1078.

49. Morris E, Thomson K, Craddock C, et al. Outcomes after alemtuzumab-containing reduced-intensity allogeneic transplantation regimen for relapsed and refractory non-Hodgkin lymphoma. Blood. 2004;104(13):3865-3871.

50. Storb R, Epstein RB, Graham TC, Thomas ED. Methotrexate regimens for control of graft-versus-host disease in dogs with allogeneic marrow grafts. Transplantation. 1970;9(3):240-246.

51. Thomas ED, Buckner CD, Banaji M, et al. One hundred patients with acute leukemia treated by chemotherapy, total body irradiation, and allogeneic marrow transplantation. Blood. 1977;49(4):511-533.

52. Deeg HJ, Storb R, Thomas ED, et al. Cyclosporine as prophylaxis for graft-versus-host disease: a randomized study in patients undergoing marrow transplantation for acute nonlymphoblastic leukemia. Blood. 1985;65(6):1325-1334.
53. Storb R, Deeg HJ, Thomas ED, et al. Marrow transplantation for chronic myelocytic leukemia: a controlled trial of cyclosporine versus methotrexate for prophylaxis of graft-versus-host disease. Blood. 1985;66(3):698-702.

54. Ringdén O, Backman L, Lönnqvist B, et al. A randomized trial comparing use of cyclosporin and methotrexate for graft-versushost disease prophylaxis in bone marrow transplant recipients with haematological malignancies. Bone Marrow Transplant. 1986;1(1):41-51.

55. Deeg HJ, Lin D, Leisenring W, et al. Cyclosporine or cyclosporine plus methylprednisolone for prophylaxis of graft-versus-host disease: a prospective, randomized trial. Blood. 1997;89(10):3880-3887.

56. Kino T, Hatanaka H, Miyata S, et al. FK-506, a novel immunosuppressant isolated from a Streptomyces. II. Immunosuppressive effect of FK-506 in vitro. J Antibiot (Tokyo). 1987;40(9):1256-1265.

57. Przepiorka D, Ippoliti C, Khouri I, et al. Tacrolimus and minidose methotrexate for prevention of acute graft-versus-host disease after matched unrelated donor marrow transplantation. Blood. 1996; 88(11):4383-4389.

58. Nash RA, Etzioni R, Storb R, et al. Tacrolimus (FK506) alone or in combination with methotrexate or methylprednisolone for the prevention of acute graft-versus-host disease after marrow transplantation from HLA-matched siblings: a single-center study. Blood. 1995;85(12):3746-3753.

59. Nash RA, Antin JH, Karanes C, et al. Phase 3 study comparing methotrexate and tacrolimus with methotrexate and cyclosporine for prophylaxis of acute graft-versus-host disease after marrow transplantation from unrelated donors. Blood. 2000;96(6):2062-2068.

60. Franklin TJ, Cook JM. The inhibition of nucleic acid synthesis by mycophenolic acid. Biochem J. 1969;113(3):515-524.

61. Suthanthiran M, Morris RE, Strom TB. Immunosuppressants: cellular and molecular mechanisms of action. Am J Kidney Dis. 1996;28(2):159-172.

62. Storb R, Yu C, Wagner JL, et al. Stable mixed hematopoietic chimerism in DLA-identical littermate dogs given sublethal total body irradiation before and pharmacological immunosuppression after marrow transplantation. Blood. 1997;89(8):3048-3054.

63. Sabry W, Le Blanc R, Labbe AC, et al. Graft-versus-host disease prophylaxis with tacrolimus and mycophenolate mofetil in HLA-matched nonmyeloablative transplant recipients is associated with very low incidence of GVHD and nonrelapse mortality. Biol Blood Marrow Transplant. 2009;15(8):919-929.

64. Zohren F, Schroeder T, Czibere A, et al. Tacrolimus and mycofenolate mofetil as GvHD prophylaxis following nonmyeloablative conditioning and unrelated hematopoietic SCT for adult patients with advanced hematologic diseases. Bone Marrow Transplant. July 26, 2010. Epub ahead of print. DOI: 10.1038/bn2010.167.

65. Bolwell B, Sobecks R, Pohlman B, et al. A prospective randomized trial comparing cyclosporine and short course methotrexate with cyclosporine and mycophenolate mofetil for GVHD prophylaxis in myeloablative allogeneic bone marrow transplantation. Bone Marrow Transplant. 2004;34(7):621-625.

66. Piñana JL, Valcárcel D, Fernández-Avilés F, et al. MTX or mycophenolate mofetil with CsA as GVHD prophylaxis after reduced-intensity conditioning PBSCT from HLA-identical siblings. Bone Marrow Transplant. 2010;45(9):1449-1456.

67. Perkins J, Field T, Kim J, et al. A randomized phase II trial comparing tacrolimus and mycophenolate mofetil to tacrolimus and methotrexate for acute graft-versus-host disease prophylaxis. Biol Blood Marrow Transplant. 2010;16(7):937-947.

68. Storb R, Pepe M, Anasetti C, et al. What role for prednisone in prevention of acute graft-versus-host disease in patients undergoing marrow transplants? Blood. 1990;76(5):1037-1045.

69. Chao NJ, Schmidt GM, Niland JC, et al. Cyclosporine, methotrexate, and prednisone compared with cyclosporine and prednisone for prophylaxis of acute graft-versus-host disease. $N$ Engl $J$ Med. 1993;329(17):1225-1230. 
70. Chao NJ, Snyder DS, Jain M, et al. Equivalence of 2 effective graftversus-host disease prophylaxis regimens: results of a prospective double-blind randomized trial. Biol Blood Marrow Transplant. 2000;6(3):254-261.

71. Ruutu T, Volin L, Parkkali T, Juvonen E, Elonen E. Cyclosporine, methotrexate, and methylprednisolone compared with cyclosporine and methotrexate for the prevention of graft-versus-host disease in bone marrow transplantation from HLA-identical sibling donor: a prospective randomized study. Blood. 2000;96(7):2391-2398.

72. Griffith JP, Kim JL, Kim EE, et al. X-ray structure of calcineurin inhibited by the immunophilin-immunosuppressant FKBP12-FK506 complex. Cell. 1995;82(3):507-522.

73. Morice WG, Brunn GJ, Wiederrecht G, Siekierka JJ, Abraham RT. Rapamycin-induced inhibition of p34cdc2 kinase activation is associated with G1/S-phase growth arrest in T lymphocytes. J Biol Chem. 1993;268(5):3734-3738.

74. Altmeyer A, Dumont FJ. Rapamycin inhibits IL-1-mediated interferon-gamma production in the YAC-1 T cell lymphoma. Cytokine. 1993;5(2):133-143.

75. Lai JH, Tan TH. CD28 signaling causes a sustained down-regulation of I kappa B alpha which can be prevented by the immunosuppressant rapamycin. J Biol Chem. 1994;269(48):30077-30080.

76. Battaglia M, Stabilini A, Roncarolo MG. Rapamycin selectively expands CD4+CD25+FoxP3+ regulatory T cells. Blood. 2005;105(12):4743-4748.

77. Antin JH, Kim HT, Cutler C, et al. Sirolimus, tacrolimus, and low-dose methotrexate for graft-versus-host disease prophylaxis in mismatched related donor or unrelated donor transplantation. Blood. 2003;102(5):1601-1605.

78. Alyea EP, Li S, Kim HT, et al. Sirolimus, tacrolimus, and low-dose methotrexate as graft-versus-host disease prophylaxis in related and unrelated donor reduced-intensity conditioning allogeneic peripheral blood stem cell transplantation. Biol Blood Marrow Transplant. 2008;14(8):920-926.

79. Ho VT, Aldridge J, Kim HT, et al. Comparison of Tacrolimus and Sirolimus (Tac/Sir) versus Tacrolimus, Sirolimus, and minimethotrexate (Tac/Sir/MTX) as acute graft-versus-host disease prophylaxis after reduced-intensity conditioning allogeneic peripheral blood stem cell transplantation. Biol Blood Marrow Transplant. 2009;15(7):844-850.

80. Rodriguez R, Nakamura R, Palmer JM, et al. A phase II pilot study of tacrolimus/sirolimus GVHD prophylaxis for sibling donor hematopoietic stem cell transplantation using 3 conditioning regimens. Blood. 2010;115(5):1098-1105.

81. Cutler C, Li S, Ho VT, et al. Extended follow-up of methotrexate-free immunosuppression using sirolimus and tacrolimus in related and unrelated donor peripheral blood stem cell transplantation. Blood. 2007;109(7):3108-3114

82. Cutler C, Stevenson K, Kim HT, et al. Sirolimus is associated with veno-occlusive disease of the liver after myeloablative allogeneic stem cell transplantation. Blood. 2008;112(12):4425-4431.

83. Peritt D. Potential mechanisms of photopheresis in hematopoietic stem cell transplantation. Biol Blood Marrow Transplant. 2006;12 (1 Suppl 2):7-12.

84. Shaughnessy PJ, Bolwell BJ, van Besien K, et al. Extracorporeal photopheresis for the prevention of acute GVHD in patients undergoing standard myeloablative conditioning and allogeneic hematopoietic stem cell transplantation. Bone Marrow Transplant. 2010;45(6):1068-1076.

85. Ruutu T, Eriksson B, Remes K, et al; Nordic Bone Marrow Transplantation Group. Ursodeoxycholic acid for the prevention of hepatic complications in allogeneic stem cell transplantation. Blood. 2002;100(6):1977-1983.

86. Blazar BR, Weisdorf DJ, Defor T, et al. Phase 1/2 randomized, placebocontrol trial of palifermin to prevent graft-versus-host disease (GVHD) after allogeneic hematopoietic stem cell transplantation (HSCT). Blood. 2006;108(9):3216-3222.
87. Van Lint MT, Uderzo C, Locasciulli A, et al. Early treatment of acute graft-versus-host disease with high- or low-dose 6-methylprednisolone: a multicenter randomized trial from the Italian Group for Bone Marrow Transplantation. Blood. 1998;92(7):2288-2293.

88. Hings IM, Filipovich AH, Miller WJ, et al. Prednisone therapy for acute graft-versus-host disease: short- versus long-term treatment. A prospective randomized trial. Transplantation. 1993;56(3): $577-580$

89. MacMillan ML, Weisdorf DJ, Wagner JE, et al. Response of 443 patients to steroids as primary therapy for acute graft-versus-host disease: comparison of grading systems. Biol Blood Marrow Transplant. 2002;8(7):387-394.

90. Lee SJ, Zahrieh D, Agura E, et al. Effect of up-front daclizumab when combined with steroids for the treatment of acute graft-versushost disease: results of a randomized trial. Blood. 2004;104(5): 1559-1564

91. Couriel DR, Saliba R, de Lima M, et al. A phase III study of infliximab and corticosteroids for the initial treatment of acute graft-versus-host disease. Biol Blood Marrow Transplant. 2009;15(12):1555-1562.

92. Alousi AM, Weisdorf DJ, Logan BR, et al. Blood and Marrow Transplant Clinical Trials Network. Etanercept, mycophenolate, denileukin, or pentostatin plus corticosteroids for acute graftversus-host disease: a randomized phase 2 trial from the Blood and Marrow Transplant Clinical Trials Network. Blood. 2009;114(3): 511-517.

93. Uberti JP, Ayash L, Ratanatharathorn V, et al. Pilot trial on the use of etanercept and methylprednisolone as primary treatment for acute graft-versus-host disease. Biol Blood Marrow Transplant. 2005;11(9):680-687.

94. Kim JG, Sohn SK, Kim DH, et al. Different efficacy of mycophenolate mofetil as salvage treatment for acute and chronic GVHD after allogeneic stem cell transplant. Eur J Haematol. 2004;73(1): 56-61.

95. Shaughnessy PJ, Bachier C, Grimley M, et al. Denileukin diftitox for the treatment of steroid-resistant acute graft-versus-host disease. Biol Blood Marrow Transplant. 2005;11(3):188-193.

96. Bolaños-Meade J, Jacobsohn DA, Margolis J, et al. Pentostatin in steroid-refractory acute graft-versus-host disease. J Clin Oncol. 2005 23(12):2661-2668.

97. Van Lint MT, Milone G, Leotta S, et al. Treatment of acute graftversus-host disease with prednisolone: significant survival advantage for day +5 responders and no advantage for nonresponders receiving anti-thymocyte globulin. Blood. 2006;107(10):4177-4181.

98. Hsu B, May R, Carrum G, Krance R, Przepiorka D. Use of antithymocyte globulin for treatment of steroid-refractory acute graft-versus-host disease: an international practice survey. Bone Marrow Transplant. 2001;28(10):945-950.

99. Lopez M, Clarkson MR, Albin M, Sayegh MH, Najafian N. A novel mechanism of action for anti-thymocyte globulin: induction of CD4+CD25+Foxp3+ regulatory T cells. J Am Soc Nephrol. 2006; 17(10):2844-2853.

100. Arai S, Margolis J, Zahurak M, Anders V, Vogelsang GB. Poor outcome in steroid-refractory graft-versus-host disease with antithymocyte globulin treatment. Biol Blood Marrow Transplant. 2002;8(3):155-160.

101. MacMillan ML, Weisdorf DJ, Davies SM, et al. Early antithymocyte globulin therapy improves survival in patients with steroid-resistant acute graft-versus-host disease. Biol Blood Marrow Transplant. 2002;8(1):40-46.

102. Martin PJ, Schoch G, Fisher L, et al. A retrospective analysis of therapy for acute graft-versus-host disease: secondary treatment. Blood. 1991;77(8):1821-1828.

103. Przepiorka D, Phillips GL, Ratanatharathorn V, et al. A phase II study of BTI-322, a monoclonal anti-CD2 antibody, for treatment of steroid-resistant acute graft-versus-host disease. Blood. 1998;92(11):4066-4071. 
104. Knop S, Hebart H, Gratwohl A, et al. Treatment of steroid-resistant acute GVHD with OKT3 and high-dose steroids results in better disease control and lower incidence of infectious complications when compared to high-dose steroids alone: a randomized multicenter trial by the EBMT Chronic Leukemia Working Party. Leukemia. 2007;21(8):1830-1833.

105. Gleixner B, Kolb HJ, Holler E, et al. Treatment of aGVHD with OKT3: clinical outcome and side-effects associated with release of TNF alpha. Bone Marrow Transplant. 1991;8(2):93-98.

106. Carpenter PA, Lowder J, Johnston L, et al. A phase II multicenter study of visilizumab, humanized anti-CD3 antibody, to treat steroidrefractory acute graft-versus-host disease. Biol Blood Marrow Transplant. 2005;11(6):465-471.

107. Byers VS, Henslee PJ, Kernan NA, et al. Use of an anti-pan T-lymphocyte ricin a chain immunotoxin in steroid-resistant acute graft-versus-host disease. Blood. 1990;75(7):1426-1432.

108. Willenbacher W, Basara N, Blau IW, Fauser AA, Kiehl MG. Treatment of steroid refractory acute and chronic graft-versus-host disease with daclizumab. Br J Haematol. 2001;112(3):820-823.

109. Anasetti C, Hansen JA, Waldmann TA, et al. Treatment of acute graft-versus-host disease with humanized anti-Tac: an antibody that binds to the interleukin-2 receptor. Blood. 1994;84(4):1320-1327.

110. Przepiorka D, Kernan NA, Ippoliti C, et al. Daclizumab, a humanized anti-interleukin-2 receptor alpha chain antibody, for treatment of acute graft-versus-host disease. Blood. 2000;95(1):83-89.

111. Bay JO, Dhédin N, Goerner M, et al. Inolimomab in steroid-refractory acute graft-versus-host disease following allogeneic hematopoietic stem cell transplantation: retrospective analysis and comparison with other interleukin-2 receptor antibodies. Transplantation. 2005;80(6):782-788

112. Massenkeil G, Rackwitz S, Genvresse I, Rosen O, Dörken B, Arnold R. Basiliximab is well tolerated and effective in the treatment of steroidrefractory acute graft-versus-host disease after allogeneic stem cell transplantation. Bone Marrow Transplant. 2002;30(12):899-903.

113. Funke VA, de Medeiros CR, Setubal DC, et al. Therapy for severe refractory acute graft-versus-host disease with basiliximab, a selective interleukin-2 receptor antagonist. Bone Marrow Transplant. 2006;37(10):961-965.

114. Martínez C, Solano C, Ferrá C, Sampol A, Valcárcel D, Pérez-Simón JA; Spanish Group for Stem Cell Transplantation (Grupo Español de Trasplante Hemopoyético y Terapia Celular). Alemtuzumab as treatment of steroid-refractory acute graft-versus-host disease: results of a phase II study. Biol Blood Marrow Transplant. 2009; 15(5):639-642.
115. Macmillan ML, Couriel D, Weisdorf DJ, et al. A phase $2 / 3$ multicenter randomized clinical trial of $\mathrm{ABX}-\mathrm{CBL}$ versus $\mathrm{ATG}$ as secondary therapy for steroid-resistant acute graft-versus-host disease. Blood. 2007;109(6):2657-2662.

116. Busca A, Locatelli F, Marmont F, Ceretto C, Falda M. Recombinant human soluble tumor necrosis factor receptor fusion protein as treatment for steroid refractory graft-versus-host disease following allogeneic hematopoietic stem cell transplantation. Am J Hematol. 2007;82(1):45-52.

117. Patriarca F, Sperotto A, Damiani D, et al. Infliximab treatment for steroid-refractory acute graft-versus-host disease. Haematologica. 2004;89(11):1352-1359.

118. Greinix HT, Volc-Platzer B, Kalhs P, et al. Extracorporeal photochemotherapy in the treatment of severe steroid-refractory acute graftversus-host disease: a pilot study. Blood. 2000;96(7):2426-2431.

119. Greinix HT, Knobler RM, Worel N, et al. The effect of intensified extracorporeal photochemotherapy on long-term survival in patients with severe acute graft-versus-host disease. Haematologica. 2006;91(3):405-408.

120. Dall'Amico R, Messina C. Extracorporeal photochemotherapy for the treatment of graft-versus-host disease. Ther Apher. 2002; 6(4):296-304.

121. Le Blanc K, Frassoni F, Ball L, et al; Developmental Committee of the European Group for Blood and Marrow Transplantation. Mesenchymal stem cells for treatment of steroid-resistant, severe, acute graft-versus-host disease: a phase II study. Lancet. 2008;371(9624): 1579-1586.

122. Von Bonin M, Kiani A, Platzbecker U, et al. Third-party mesenchymal stem cells as part of the management of graft-failure after haploidentical stem cell transplantation. Leuk Res. 2009; 33(12):e215-e217.

123. Kebriaei P, Isola L, Bahceci E, et al. Adult human mesenchymal stem cells added to corticosteroid therapy for the treatment of acute graft-versus-host disease. Biol Blood Marrow Transplant. 2009;15(7):804-811.

124. Martin PJ, Uberti JP, Soiffer RJ, et al. Prochymal improves response rates in patients with steroid-refractory acute graft versus host disease (SR-GVHD) involving the liver and gut: results of a randomized, placebo-controlled, multicenter pPhase III trial in GVHD. Biol Blood Marrow Transplant: J Am Soc Blood Marrow Transplant. 2010;16(2):S169-S170.
Transplant Research and Risk Management

\section{Publish your work in this journal}

Transplant Research and Risk Management is an international, peerreviewed open access journal focusing on all aspects of transplantation and risk management to achieve optimal outcomes in the recipient improving survival and quality of life. The journal welcomes submitted papers covering original research, basic science, clinical studies,

\section{Dovepress}

reviews \& evaluations, guidelines, expert opinion and commentary, case reports and extended reports. The manuscript management system is completely online and includes a very quick and fair peer-review system, which is all easy to use. Visit http://www.dovepress.com/ testimonials.php to read real quotes from published authors. 